\title{
Eryck Abecassis
}

\section{What is noise (music) to you?}

I like to define noise with its mathematical and physical definitions.

In those domains, noises are all the non-desirable, distorted events in the normal signal.

Noise music is also a way to put an ear into unknown territories.

\section{Why do you make it?}

Because I always have, since the beginning of my musical practice; as long as I can remember, noise has been present.

Also I cannot imagine myself having a thought without envisaging its "disturbing counterpart."

Just for spirit sanity. 
NOISE IN AND AS MUSIC 


\title{
Inside Fama's House: listening, intimacy, and the noises of the body
}

\author{
Martin Iddon
}

Fama, the Roman embodiment of "rumor," enjoys a mixed reputation. Virgil complained that rumor was "the swiftest of all evils/malum qua non aliud velocius ullum," "1 while Shakespeare was convinced that none could stop the "vent of hearing when loud Rumour speaks."2 Even though Ovid claimed that rumor "loves to tangle true with false/quae veris addere falsa gaudet" and Shakespeare had Rumour herself proclaim "[u]pon my tongue continual slanders ride," ${ }^{3}$ in truth, for the most part it seems that the veracity of the reports of Fama are typically unquestionable. While the precise sort of fame she presages may be unwelcome-and this is certainly the "evil" of which Virgil speaks-that Fama is an accurate witness of what she has heard is hardly in question. ${ }^{4}$ If there is slander in her words, it originates in the lies that she accurately and truthfully reports. The ways in which the Latin word, fama, intersects with related words is, too, suggestive. The Greek, phème, from which fama derives, does bespeak "rumor" or "gossip," but it is also an "utterance" or a "voice." The Latin rumor has, for a contemporary English-speaking audience, become intermingled with fama. The French rumeur, which derives from it, makes clear the elision; it has two meanings: an indeterminate noise and the

1 Publius Vergilius Maro, Aeneid IV, 74.

2 William Shakespeare, Henry IV, Part II, Prologue, 2.

3 Publius Ovidius Naso, Metamorphoses IX, 138-39; William Shakespeare, Henry IV, Part II, Prologue, 6.

4 See Nancy Zumwalt, "Fama Subversa: Theme and Structure in Ovid Metamorphoses 12," California Studies in Classical Antiquity (1977), vol. 10: 221, n. 11. 
communication of a piece of gossip..$^{5}$ Fama, then, might represent the sorts of noise concealed by the noises of rumor: quiet whispering, rustling murmurs, hidden by the louder noises which rumor has come to designate, as, perhaps most obviously, in Russolo's L'Arte dei rumori (1913).

In the first instance, however, my concern is with the site of listening. Importantly, as Due notes, while Virgil's and Shakespeare's conceptions of Rumour portray her as a horrific beast, abroad in the land, Ovid concentrates not on the creature Fama but, instead, on her dwelling place: ${ }^{6}$

\begin{abstract}
Orbe locus medio est inter terrasque fretumque caelestesque plagas, triplicis confinia mundi; unde quod est usquam, quamvis regionibus absit, inspicitur, penetratque cavas vox omnis ad aures: Fama tenet summaque domum sibi legit in arce, innumerosque aditus ac mille foramina tectis addidit et nullis inclusit limina portis; nocte dieque patet: tota est ex aere sonanti, tota fremit vocesque refert iteratque quod audit; nulla quies intus nullaque silentia parte, nec tamen est clamor, sed parvae murmura vocis, qualia de pelagi, siquis procul audiat, undis esse solent, qualemve sonum, cum Iuppiter atras increpuit nubes, extrema tonitrua reddunt.
\end{abstract}

5 A further, curious elision might be noted: the slang word scuttlebutt too refers to gossip (and is a possible meaning of the contemporary French rumeur), but is derived from a nautical term for the water butt on a ship; in contemporary usage, this has to do with the idea of rumors being spread around the workplace water cooler. The English word noise itself stems from the Latin nausea, which is to say seasickness, in turn derived from Greek vaṽ $\varsigma$, a ship. Rumor and noise, in a linguistic sense, are profoundly interwoven concepts from the outset, even if the precise relationship between them is in constant flux. Fama too, it should be remembered, has also had the meaning of "reputation" in medieval Europe, though it was the "reputation" an individual had as constructed through what was said about him or her. See Thelma Fenster and Daniel Lord Smail (eds.), Fama: The Politics of Talk \& Reputation in Medieval Europe (Ithaca: Cornell University Press, 2003).

6 See Otto Steen Due, Changing Forms: Studies in the Metamorphoses of Ovid (Copenhagen: Gyldendal, 1974), 148-49. 
At the world's center lies a place between The lands and seas and regions of the sky, The limits of the threefold universe, Whence all things everywhere, however far, Are scanned and watched, and every voice and word

Reaches its listening ears. Here Rumour dwells,

Her chosen home set on the highest peak,

Constructed with a thousand apertures

And countless entrances and never a door.

It's open night and day and built throughout

Of echoing bronze; it all reverberates,

Repeating voices, doubling what it hears.

Inside, no peace, no silence anywhere,

And yet no noise, but muted murmurings

Like waves one hears of some far-distant sea,

Or like a last late rumbling thunder roll.

Ovid, Metamorphoses XII: 39-52

Where, for Virgil, Fama is abroad in the world, spreading rumor wherever she passes, in Ovid's conception Fama is a receiver, hearing all. Ovid proposes that many dwell alongside Fama here: Credulitas (credulity), Error (error), Laetitia (delight), Susurri (whispers), Seditio (sedition), and Timores (fear). Against this essentially negative characterization of what happens in Fama's house, in what follows I intend to suggest something rather different. I propose that the site of listening-Fama's house itself-may be understood as a metaphorical description of the listening body and the sorts of noises that that body encounters as a listening body. In developing this essentially corporeal, visceral approach to listening, I simultaneously argue that listening is essentially an intimate act, an activity that is, at heart, private and bodily. As Michel de Certeau puts it, linking bodies and listening in direct terms: "Through the legends and phantoms whose audible citations continue to 
haunt everyday life, one can maintain a tradition of the body, which is heard but not seen."

\section{2}

Reading Ovid's description of Fama's house, one might hear, at first blush, echoes of an obscure text by Leibniz in which a perfect political system is described through the allegory of the "Palace of Marvels":

These buildings will be constructed in such a way that the master of the house will be able to hear and see everything that is said and done without himself being perceived, by means of mirrors and pipes, which will be a most important thing for the State, and a kind of political confessional. ${ }^{8}$

Yet hearing is, surely, first hearing oneself in the internal cavity of one's own skull, before it is hearing anything else, and the question of who is master of such a house is hardly a simple one. Living with the sounds of one's own voice, "Is that really how I sound?" one might enquire of a recording of it.

The body barely allows the possibility of observing oneself. The visual is concerned with looking at others. Yet the aural turns inward before it turns outward. Not only this but, as Wannenwetsch emphasizes, hearing precedes seeing: "In the womb, and in our first days on earth, we see only very indistinctly. We do not initially identify our mother visually at all; we get to know her first of all precisely when she talks to us." Nancy goes further.

7 Michel de Certeau, The Practice of Everyday Life, trans. Steven Rendall (Berkeley: University of California Press, 1984), 163.

8 Gottfried Wilhelm Leibniz, quoted in Jacques Attali, Noise: The Political Economy of Music, trans. Brian Massumi (Minneapolis: University of Minnesota Press, 1985), 7.

9 Bernd Wannenwetsch, "Take Heed What Ye Hear': Listening as a Moral, Transcendental and Sacramental Act," Journal of the Royal Musical Association, vol. 135, Special Issue no.1 (2010): 96. 
Asserting, with Wannenwetsch, that "the body was conceived in darkness," he observes that the body's uterine existence was "shaped in Plato's cave, as the cave itself: prison or tomb of the soul." Yet though Nancy suggests that the "cave-body is the space of the body seeing itselffrom within,"10 surely Wannenwetsch is closer to the mark in his implicit suggestion that such a cave-body is the space of the self hearing itself from within. ${ }^{11} \mathrm{It}$ is in this sense that Serres is able to claim that music "built our house before we were born as speaking beings - and not only in the vibrating enclosure of the uterus-and paved the way for our collective existence; the social contract, hidden from all languages, can be heard indistinctly in its orchestration." ${ }^{12}$ Like Serres, Nancy asserts the primacy of hearing in the womb over the later sense of sight, in asking " $[\mathrm{w}]$ hat is the belly of a pregnant woman, if not the space or the antrum where a new instrument comes to resound, a new organon, which comes to fold in on itself, then to move, receiving from outside only sounds, which, when the day comes, it will begin to echo through its cry?"13 Yet, further, Nancy suggests that the house that was built before birth is inescapable. In listening, one is always in some sense still "in the cave": "it is always in the belly that we-man or woman-end up listening. The ear opens onto the sonorous cave that we then become." ${ }^{14}$

Serres's account of listening hinges on precisely the question of hearing the sound of one's own body: health comes when the noise of the body's

10 Jean-Luc Nancy, “Corpus," Corpus, trans. Richard A. Rand (New York: Fordham University Press, 2008), 67.

11 See Martin Iddon, "Plato's Chamber of Secrets: On eavesdropping and truth(s)," Performance Research (2010), 15, no.3: 6-10.

12 Michel Serres, The Five Senses: A Philosophy of Mingled Bodies, trans. Margaret Sankey and Peter Cowley (London: Continuum, 2008), 123.

13 Jean-Luc Nancy, Listening, trans. Charlotte Mandell (New York: Fordham University Press, 2007), 37.

14 Nancy, Listening, 37. 
organs is silenced. ${ }^{15}$ Serres's account is-hardly surprising in the context of a description of healing at Epidauros-reliant upon an ancient tradition of thought: "[i]t is a commonplace of ancient philosophical writing that internal uproar, the noise of the passions or of a mind divided against itself, prevents us from listening properly to the healing words of philosophy." 16

For Nancy, almost the opposite is the case. Hearing, the hearing of oneself in particular, is at the origin of subjectivity:

Perhaps we should thus understand the child who is born with his first cry as himself being — his being or his subjectivity—the sudden expansion of an echo chamber, a vault where what tears him away and what summons him resound at once, setting in vibration a column of air, of flesh, which sounds at its apertures: body and soul of some one new and unique. Someone who comes to himself by hearing himself cry (answering the other? calling him?), or sing, always each tome, beneath each word, crying or singing, exclaiming as he did by coming into the world."17

It is not a question of some return to a mythical time of full wholeness that Nancy proposes, rather more that listening is always a memory or an echo of "the resonance of being, or ... being as resonance." Silence, in this case, would be neither privation nor the sound of health, as Serres has it, but "an arrangement of resonance," as when, recalling Cage's experience in the anechoic chamber, "in a perfect condition of silence you hear your own body resonate, your own breath, your heart and all its resounding cave." ${ }^{18}$ In this, at

15 Serres, The Five Senses, 85.

16 William Fitzgerald, "Listening, Ancient and Modern," Journal of the Royal Musical Association, 135, Special Issue no.1 (2010): 33.

17 Nancy, Listening, 17-18.

18 Nancy, Listening, 21. 
least, Nancy and Serres agree: an escape from the cave, from the chamber of listening, is not possible, even if it were desirable:

No matter how far I travel, poor subject that I am, I never manage to put any distance between myself and the droning of the language that shaped me. What merely resonated within my mother's womb is a clamour in this stone conch, and finds itself echoed in my innermost ear. ${ }^{19}$

Not for nothing does Serres emphasize the link to a shell, not only a protective casement for the body but also that potent metaphor for the ear in both shape and function. The rumors that Ovid hears are, finally, like the waves "of some far-distant sea." The shell placed against the ear-literally, as well as metaphorically, shell-to-shell-the body hears itself. As Bachelard neatly summarizes it, "[w]e might say that the inside of a man's body is an assemblage of shells." ${ }^{20}$ Bachelard states, too, that "[e]verything about a creature that comes out of a shell is dialectical. And since it does not come out entirely, the part that comes out contradicts the part that remains inside. The creature's rear parts remain imprisoned in the solid geometric forms." ${ }^{21}$ The dichotomy of inside and outside is surely not literally meant. Here, once the link between shells and ears has been made, the return to the transcendent Platonic world of pure forms can be seen: if the part within the shell, within the womb, or within the cave- however one conceives it - is in contradiction with the outer part- that which looks on the world-it is in listening that some approach to the transcendent experience of the Platonic real might, perhaps, be found.

19 Serres, The Five Senses, 93.

20 Gaston Bachelard, The Poetics of Space, trans. Maria Jolas (Boston: Beacon, 1994), 113.

21 Bachelard, The Poetics of Space, 108. 


\section{3}

That listening is always, first and foremost, a listening to the self, if not of the self, is suggested by René Daumal:

Ecoute bien pourtant. Non pas mes paroles, mais le tumulte qui s'elève en ton corps lorsque tu t'écoutes. Ce sont des rumeurs de combat, des ronflements de dormeur, des cris de bêtes, le bruit de tout un univers.

Listen well. Not to my words, but to the noises that build up inside your body when you listen to yourself. They are the rumors of combat, the snores of sleepers, the cries of animals, the noise of an entire universe. ${ }^{22}$

Elsewhere, Daumal stresses the point, with a combination of imagery of particular relevance here:

\section{[...] peau pleine de rumeurs aux échos de villes souterraines [...] \\ [...] skin full of rumors from the echoes of subterranean cities $[\ldots] .{ }^{23}$}

The poem from which this second quotation is drawn is entitled "A perdre sens": to lose one's way, to be sure, but also to lose one's sense or, for that matter, meaning. Nancy plays on the multiple meanings of sens throughout his account of listening.

As he puts it, "sensing [sentir] (aisthesis) is always a perception [ressentir], that is, a feeling-oneself-feel [se-sentir-sentir]: or, if you prefer, sensing is a subject, or it does not sense." ${ }^{24}$ The sensing subject is, in Nancy's terms, the

22 René Daumal, Le Contre-ciel suivi de Les dernières Paroles du poète, trans. Kelton W. Knight (New York: Tusk Ivories, 1990), 54. Translation modified.

23 Daumal, Le Contre-ciel, 118. Translation modified.

24 Nancy, Listening, 8. 
only subject. Without sensing, there is no subject, no self. Those subterranean cities are redolent, too, of Serres's description of hearing the sound of one's own voice:

We can neither speak nor sing without the feedback loop which guarantees the audibility of our own voice. The ear guarantees and regulates the mouth, which emits noise in part for the speaker, in part for others, who in turn guarantee other feedback loops. Intuitively we imagine a large prostrate body, buried underground, the marble pavilion of its ear jutting out, its dark mouths speaking and shouting for millennia through the plunging cliff-face. ${ }^{25}$

Significant, too, is Nancy's re-iteration that "the ears don't have eyelids." No more does Fama's house have doors. The sound cannot, or cannot simply, be shut out. As Bull observes, in the case of Odysseus's encounter with the Sirens: "[i]t is not the seeing or touching of the Sirens that motivates Odysseus but the hearing of their song; it literally enters him." ${ }^{26}$ Just the same sort of penetration, or opening up, is at play in de Certeau's description of the voices of bodies - though here perhaps it is a question of a reclamation, a return rather than an echo-in which psychoanalysis moves from "a 'science of dreams' to the experience of what speaking voices change in the dark grotto of the bodies that hear them." As de Certeau has it, this chamber-grotto or cave-becomes a "plural body in which ephemeral rumors circulate." ${ }^{27}$ Daumal's subterranean city is, too, a body. The cave, Fama's house, and the body become one and the same subject here in the juxtaposition of Daumal, Nancy, and Serres.

\footnotetext{
25 Serres, The Five Senses, 110.
}

26 Michael Bull, "Thinking about Sound, Proximity, and Distance in Western Experience: The Case of Odysseus's Walkman," in Hearing Cultures: Essays on Sound, Listening and Modernity, ed. Veit Erlmann (Oxford: Berg, 2004), 178.

27 de Certeau, Practice of Everyday Life, 162. 
It is in listening, then, that this is most potent, in the case of the resonant chamber of the body, which already experiences the distance of an echo [renvoi]. To listen is to be penetrated by sound in Nancy's terms and, more significantly, to be opened up by sound: "it opens me inside me as well as outside, and it is through such a double, quadruple, or sextuple opening that a 'self' can take place." ${ }^{28}$ The openings of Nancy's listening might be seen as little different from the countless entrances of Fama's house, the body itself.

It might be necessary in such a context to revise that notion that suggests that listening tilts at pure internality, pure intimacy of the self, since " $[t]_{0}$ be listening is to be at the same time outside and inside, to be open from without and from within, hence from one to the other and from one in the other." ${ }^{29}$ Even the statement that hearing is first the hearing of oneself must be revised, since listening in such terms then becomes the hearing of others within oneself, resounding as one hears oneself too. Listening becomes a "sharing of an inside/ outside, division and participation, de-connection and contagion." ${ }^{30}$ It is notable that the intermingling of sound, listening, and illness that pervades Serres's account is retained by Nancy too, even if in modified form.

This double listening is emphasized by Wannenwetsch: "[I]n listening to a piece of music, we listen not only to the musicians, but also to the sound of our own body resonance, as a way of responding to the spirit of the piece and its truth that claims and seeks to transform us." ${ }^{31}$ The resonance of the

28 Nancy, Listening, 14.

29 Nancy, Listening, 14.

30 Nancy, Listening, 14.

31 Wannenwetsch, "Take Heed What Ye Hear," 102. No surprise, then, that in Wannenwetsch's essentially theological account, the Word is made flesh through the bodily resonance of song: "If psalmody does not engage scripture as script, but scripture as voice-listening to a word that cannot be 'interpreted' but only 'incorporated': when the human body—as the chamber of resonance of the sounding scripturetakes on scripture's own vibrating frequency, so to speak" (p. 100). Listening to the resonance of the self is, in his terms, another kind of truth-unveiling. As Wannenwetsch conceives it, this is, in part at least, what it would mean to be "all ears," "perceptive and responsive to God's address and the story of his ways with mankind. That is why the 'heart' is given prominence in the Shema as the 'organ' in which all sensual perception, thought and will are given direction." (p. 93). 
self, in the act of listening, not only opens the body up to the self, it changes the self as it listens to itself. The sonorous place is not, as Nancy stresses, "a place where the subject comes to make himself heard," 32 even if the first echo is that of one's own voice and, furthermore, even if "the sound that penetrates through the ear propagates throughout the entire body something of its effects, which could not be said to occur in the same way with the visual signal." 33 Rather "it is a place that becomes subject insofar as sound resonates there." The reverberation chamber of listening becomes, in such a construction, "nothing other than the body from end to end." Meaning [sens] is already in a state of return before it has acquired meaningfulness, "completely ahead of signification, meaning in its nascent state, in the state of return [renvoi] for which the end of this return is not given (the concept, the idea, the information)." Far from being in any sort of progress toward meaningfulness, the listening body's sense is confined by "the state of return without end, like an echo that continues on its own and that is nothing but this continuance going in a decrescendo, or even in moriendo." 34

Nancy's version of the eternal return of the self here is, itself, echoed in Ashbery's words, which themselves recall the central metaphorical descriptions of the body at play here: it is rock, from which a cave might be carved by the water. His description of a wave is obviously pertinent in any consideration of the wave that sound cannot but be: "Like a wave breaking on a rock, giving up/Its shape in a gesture which expresses that shape." ${ }^{35}$ This need not be the self-annihilation of the work of art or the transience of the subject as such, but only, as Nancy's thinking suggests, the gradual echoing

32 Nancy, Listening, 17.

33 Nancy, Listening, 14-15.

34 Nancy, Listening, 27.

35 John Ashbery, "Self-Portrait in a Convex Mirror," Self-Portrait in a Convex Mirror (Manchester: Carcanet, 1985), 73. 
moriendo of the self in the body. ${ }^{36}$ Indeed, Nancy comes close to making the same argument. Situating listening as the sense of which other senses are, in a certain context, themselves echoes, he remodulates, once again, his central theme: "Sense, here, is the ricochet, the repercussion, the reverberation: the echo in a given body, even as this given body, or even as the gift to self of this given body." ${ }^{37}$ Nancy recalls Wittgenstein's imagined experience of listening to a sound disassociated from its timbre, and that Wittgenstein took timbre as a particular instantiation of his notion of private experience (which is to say, in Nancy's reading, experience which is not communicable).$^{38}$ Yet Nancy's conclusions stray some way from Wittgenstein's. Unwilling to brook the incommunicable as such, Nancy suggests instead that "timbre is communication of the incommunicable: provided it is understood that the incommunicable is nothing other, in a perfectly logical way, than communication itself, that thing by which a subject makes an echo-of self, of the other, it's all one-it's all one in the plural." ${ }^{39}$ Communication, listening, sense, and meaning all resound inside and between bodies and, if Nancy's underlying notion that the self is constituted in this eternal returning echo, being in his terms is neither singular nor plural, neither outside nor inside. Nevertheless, it is both bodily and fundamentally intimate.

\section{4}

De Certeau hits on precisely the intersection between enunciation, listening and intimacy, recalling in his description both Wittgensteinian

36 See, for instance, Michael E. Hattersley, Socrates and Jesus: the Argument That Shaped Western Civilisation (New York, NY: Algora, 2009), 189; or, Jody Norton, Narcissus sous rature: Male Subjectivity in Contemporary American Poetry (Cranbury: Associated University Presses, 2000), 203.

37 Nancy, Listening, 40.

38 See Ludwig Wittgenstein, “Notes for Lectures on 'Private Experience' and 'Sense Data," Philosophical Occasions, 1912-1951 (Indianapolis: Hackett, 1993), 200-88.

39 Nancy, Listening, 41. 
incommunicability and the urgency of echoing exchange that is central to Nancy's description:

\begin{abstract}
"There are" everywhere such resonances produced by the body when it is touched, like "moans" and sounds of love, cries breaking open the text that they make proliferate around them, enunciative gaps in a syntagmatic organization of statements. They are the linguistic analogues of an erection, or of a nameless pain, or of tears: voices without language, enunciations flowing from the remembering and opaque body when it no longer has the space that the voice of the other offers for amorous or indebted speech. Cries and tears: an aphasic enunciation of what appears without one's knowing where it came from (from what obscures debt or writing of the body) without one's knowing how it could be said except through the other's voice. ${ }^{40}$
\end{abstract}

The key relationships between the ideas presented thus far are intertwined in de Certeau's account. He says, first, that "[ $t]$ hese contextless voice-gaps, these 'obscene' citations of bodies, these sounds waiting for a language, seem to certify, by a 'disorder' secretly referred to an unknown order, that there is something else, something other." The echo of the impossibility of communication is evoked again here, but, more potently, he continues: "they narrate interminably (it goes on murmuring endlessly) the expectation of an impossible presence that transforms into its own body the traces it has left behind." ${ }^{11}$ The ceaseless murmur (this, too, a trace of the Latin rumor) echoes into selfhood, even without wholly fulfilling the promise of full presence. Through the penetration of the body by rumor, the body, resounding, is transformed. That desire for the resonance to begin to signify a birth to full presence is highlighted by Serres, too, in a similar context:

\footnotetext{
40 de Certeau, Practice of Everyday Life, 163.

41 de Certeau, Practice of Everyday Life, 163-64.
} 
Global, integral, already abstract hearing, seeking unity, fills volumes: boxes, cases, houses, prisons, theatres, cities, circuses, hells and forests, marine expanses on which the musician's severed head, forgotten, detached, drifts on towards distant islands and sings, pervading the wind that sweeps between sky and waves. And my whole body, a music or language box, resonance chamber, resounding gong; and my local group, an assembly sometimes found in the theatre, for contemplation. ${ }^{42}$

In a similar list, a little later in his account, Serres emphasizes that the resonant chamber of the body is also an intimate space, a home for the self:

I am the home and hearth of sound, hearing and voice all in one, black box and echo, hammer and anvil, echo chamber, music cassette, pavilion, question mark drifting through the space of meaningful or meaningless messages, emerging from my own shell or drowning in the sound waves, I am nothing but empty space and a musical note, I am empty space and note combined. ${ }^{43}$

Again, the reiteration is of bodies, caves, and shells—all boxes as Serres insistsbut also the homely site of the self. He demands that the bodily experience of sound remains poised between meaningfulness and meaninglessness, both empty and full. Such a positing of the body as resonant home recalls Fama's house, of course, but also points toward the way in which Bachelard conceives

42 Serres, The Five Senses, 138. The severed musician's head mentioned by Serres here refers to the myth that, even after his death, Orpheus's head continued to sing as it was washed down the Hebrus. The death of Orpheus is recounted by Ovid in Metamorphoses XI: 1-60. The image of Orpheus's severed head was a relatively popular nineteenth-century image in painting, featuring in work by Gustave Moreau, Jean Delville, and John William Waterhouse. The head of Orpheus also plays a central part in Russell Hoban's novel, The Medusa Frequency (London: Cape, 1987).

43 Serres, The Five Senses, 141. 
of the poetics of the home, an aesthetics which might prove fruitful when extended to its bodily analogue. ${ }^{44}$

Bachelard certainly makes the necessary links, if implicitly. His description of the house conjoins it directly with the self, not least since his concern is with the intersection of space and psychoanalytic theory:

thanks to the house, a great many of our memories are housed, and if the house is a bit elaborate, if it has a cellar and a garret, nooks and corridors, our memories have refuges that are all the more clearly delineated. All our lives we come back to them in our daydreams. A psychoanalyst should, therefore, turn his attention to this simple localization of our memories. I should like to give the name of topoanalysis to this auxiliary of psychoanalysis. Topoanalysis, then, would be the systematic psychological study of the sites of our intimate lives. ${ }^{45}$

His statement that "a knowledge of intimacy, localization in the spaces of our intimacy is more urgent than determination of dates" also recalls more recent discussion of sound and space, in just this mode of constructing the intimate space of the home while abroad in the world. ${ }^{46}$ Michael Bull, for one, extrapolates much from Berkeley's note that "bodies and external things are not properly the object of hearing; but only sounds, by the mediation whereof the idea of this or that body or distance is suggested to

\footnotetext{
44 It should be noted that Bachelard himself is leery of the use of image as if it were metaphor, observing that Bergson's use of the word drawer is almost always as a disdainful metaphor. This seems to Bachelard to be "a good example for demonstrating the radical difference between image and metaphor. I shall therefore insist upon this difference before returning to my examination of the images of intimacy that are in harmony with drawers and chests, as also with all the other hiding-places in which human beings, great dreamers of locks, keep or hide their secrets" (Bachelard, Poetics of Space, 74). I do not, then, intend to suggest that Bachelard would necessarily have sympathized with the way in which I deploy his thought here.
}

45 Bachelard, Poetics of Space, 8.

46 Bachelard, Poetics of Space, 9. 
his thoughts." ${ }^{47}$ Jonathan Rée's account claims, following this, that hearing should be understood as a contact sense and that, more pertinently here, "[s] ounds, to use a phrase of Berkeley's, are perhaps 'as near to us as our own thoughts." ${ }^{48}$ It is from this matrix that Bull identifies an absence of the aural in considerations of space and distance. ${ }^{49}$ Raymond Williams, Bull stresses, would be likely to have found nothing concerning in the portable, intimate homely spaces of (then) Walkmans or (now) iPods: "It is not living in a cut off way, not in a shell that is just stuck. It is a shell you can take with you, which you can fly to places that previous generations could never imagine visiting." ${ }^{50}$ Adorno, by contrast, "never succumbed to the temptation to split off spheres of experience in his analysis of Western consumer culture; for him the experiences of the street and the spaces of the home were always intimately linked." ${ }^{11}$ Such listening activities, the taking with one of one's own portable shell, are

about the desire for proximity, for a mediated presence that shrinks space into something manageable and habitable. Sound, more than any other sense, appears to perform a largely utopian function in this desire for proximity and connectedness. Mediated sound reproduction enables

47 George Berkeley, An Essay Towards a New Theory of Vision (Cirencester: Echo Library, 2005 [1709]), 19 .

48 Jonathan Rée, I See a Voice: A Philosophical History of Language, Deafness and the Senses (London: Flamingo, 2000), 35-36. Rée also notes that "it is not difficult to make something erotic of the idea that sounds have to enter into our bodies before they can be heard" (p. 35). Something of the same sense can clearly be felt in Nancy's account of a penetration and opening up of the body by sound.

49 It should be noted that, since Bull's account, the ground has shifted at least a little with the publication of volumes such as Barry Blesser and Linda-Ruth Salter's Spaces Speak, Are You Listening? Experiencing Aural Architecture (Cambridge: The MIT Press, 2006).

50 Raymond Williams, Television: Technology and Cultural Form (New York: Routledge, 2003), 161; quoted in Bull, "Thinking about Sound, Proximity, and Distance,"174.

51 Bull, "Thinking about Sound, Proximity, and Distance," 176. 
consumers to create intimate, manageable, and aestheticized spaces in which they are increasingly able to, and desire to, live. ${ }^{52}$

This sort of activity, then, is properly nostalgic, whatever its technological foundations. Perhaps in simulated form at least, this approach to listening nears an answer to the question Bachelard asks, even if only in part:

Transcending our memories of all the houses in which we have found shelter, above and beyond all the houses we have dreamed we lived in, can we isolate an intimate, concrete essence that would be a justification of the uncommon value of all of our images of protected intimacy?53

Even so, Bachelard's description is not without a particular desire for the, in this context, almost wholly unobtainable. He asks, too: "How ..., in these fragments of space, did the human being achieve silence? How did he relish the very special silence of the various retreats of solitary daydreaming?"54 Bachelard's response echoes, at one remove, Adorno's. Bachelard's critique of a certain philosophical position - that of withdrawal into 'pure' thoughttakes on an added resonance in this case:

Outside and inside are both intimate - they are always ready to be reversed, to exchange their hostility.... Intimate space loses its clarity, while exterior space loses its void, void being the raw material of possibility of being. We are banished from the realm of possibility.

In this drama of intimate geometry, where should one live? The philosopher's advice to withdraw into oneself in order to take one's place in existence, loses its value, and even its significance, when the supplest

52 Bull, “Thinking about Sound, Proximity, and Distance," 177.

53 Bachelard, Poetics of Space, 3.

54 Bachelard, Poetics of Space, 9. 
image of 'being-there' has just been experienced through the ontological nightmare of this poet [Henri Michaux]..$^{55}$

No surprise, in the light of what has been outlined thus far, that Michaux's account is precisely to do with sound. Indeed, it is not merely sound that concerns Michaux, but something very precise: the long rumbling of distant thunder, which Ovid paired with the distant crashing of the sea:

L'espace, mais vous ne pouvez concevoir, cet horrible en dedans-en dehors qu'est le vrai espace.

Certaines (ombres) surtout se bandant une dernière fois, font un effort désespéré pour 'être dans leur seule unité.' Mal leur en prend. J'en rencontrai une.

Détruite par châtiment, elle nétait plus qu'un bruit, mais énorme.

Un monde immense l'entendait encore, mais elle n'était plus, devenue seulement et uniquement un bruit, qui allait rouler encore des siècles mais destiné à séteindre complètement, comme si elle n'avait jamais été.

Space, but you cannot even conceive the horrible inside-outside that real space is.

Certain (shades) especially, girding their loins one last time, make a desperate effort to "exist as a single unity." But they rue the day. I met one of them.

Destroyed by punishment, it was reduced to a noise, a thunderous noise. An immense world still heard it, but it no longer existed, having become simply and solely a noise, which was to rumble on for centuries longer, but was fated to die out completely, as though it had never existed. ${ }^{56}$

55 Bachelard, Poetics of Space, 217-18.

56 Henri Michaux, Nouvelles de l'étranger (Paris: Mercure de France, 1952); quoted in Bachelard, Poetics of Space, 216-17. (Translation as it appears in Bachelard.) 
Bachelard, through Michaux, ties together many of the fundamental concerns of the above. Bachelard reads in Michaux a description of "a spirit that has lost its 'being-there' [être-là], one that has so declined as to fall from the being of its shade and mingle with the rumors of being, in the form of meaningless noise, of a confused hum that cannot be located."Yet Bachelard is unconvinced by this seeming fall from grace. He argues that the spirit always was what it is in Michaux's prose poem: "a sonorous echo." As Bachelard concludes, being in the world, being the resonant chamber of the self that is constituted in selfhood only by the recurring echoing of the self itself, " $t]$ he hum of the being of rumors continues both in time and in space." 57

57 Bachelard, Poetics of Space, 217. 